\title{
Hazards identification and risk analysis in surface mines of Pakistan using fault tree analysis technique
}

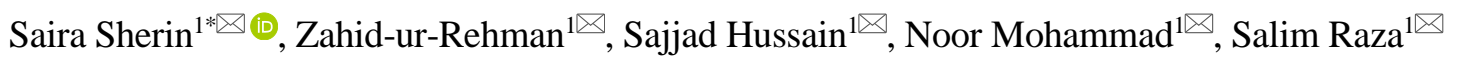 \\ ${ }^{1}$ University of Engineering and Technology, Peshawar, Peshawar, 25000, Pakistan \\ *Corresponding author: e-mail sairsherin@uetpeshawar.edu.pk, tel. +00923339243760
}

\begin{abstract}
Purpose. Technology has advanced significantly but still mining industry faces a higher number of accidents. The purpose of the research is to identify the common hazards and associated risk which are the root causes of accidents in surface mines of Pakistan and to suggest the preventive measures to enhance safety at workplace.

Methods. Integrated approach used in this research work involves: collection of mine accidents data from related Government departments; occupational safety data collection from mine sites with questionnaire; fault tree analysis method applied based on three groups of factors/causes obtained from 3E's Model i.e. Engineering, Education and Enforcement that causes accidents in mine; risk assessment and suggestion of preventive measures.

Findings. In this study forty three root causes of accidents in surface mines are identified and presented as basic events and undeveloped events in the Fault Trees. A compressed picture of the root causes is revealed leading to accidents in mine. The main causes identified are human errors, unsafe operating procedure, lack of machinery, lack of personal protective equipment, environmental and haulage related hazards and violation of law.
\end{abstract}

Originality. The root causes of accidents in surface mines have been identified. For the first time, the visual paths to accidents causation in surface mines of Pakistan are outlined through fault tree analysis technique.

Practical implications. The identified causes of accidents along with the suggested preventive measures can be used to avoid/curtail the number and severity of accidents in surface mines and can save lives of workers and economy.

Keywords: hazards identification, surface mine, accidents, fault tree analysis, risk assessment, preventive measures

\section{Introduction}

Mining industry contributes to the economic growth of a country. Besides providing employment, the products obtained from mining are used in various industries like medicines, construction, agriculture etc. [1], [2]. Despite these benefits, mining is among the hazardous tasks and involves extensive health and safety risk to mine workers [3]. In mines the unsafe conditions bring number of accidents which results in loss of lives, serious and minor injuries and economical loss.

Mine accident is an unplanned and undesirable event which occurs due to presence of hazards in mine. Identification of hazards and analysis of associated risk is important to reduce number of accidents. The number of accidents depends on the geology, presence of hazards and the safety system of the mine. Improper management of hazards and risks associated with mining activities causes mine disasters. Fall from height, slippage of foot, fall of rocks, fly rocks, inappropriate machinery and haulage etc. are the common safety hazards while dust, noise, ergonomics and stress are health hazards in the surface mines [4]-[9]. These risks can be controlled by proper management system.

Risk management process is a systematic approach which involves three main processes i.e. establishment of context, assessment of risk and treatment of risk [10]. Risk assessment is applied to understand uncertainty and the risk associated in wideranging perspective for better decisions and actions [11], [12]. Objective of this research is to identify the common hazards and the risk associated which are the root causes of accidents in surface mines through risk assessment technique.

\subsection{Accidents in surface mines of Pakistan: A brief overview}

In Pakistan, according to law, the mine accidents are report-ed to the Inspectorate of Mines Department, in each province. Thousands of workers employed in surface mines, are exposed to various hazards. Due to these hazards they face accidents frequently. Mostly fatal accidents are reported while the minor accidents are not given much importance. Unfortunately, in some provinces the record of the accidents 
data is not properly available. Figure 1 describes the occupational accidents data from 2010 to 2019, obtained from the Inspectorates of Mines Khyber Pakhtunkhwa, Punjab and Sindh, which shows that number of fatalities is quite higher in surface mines of sandstone and marble than other minerals.

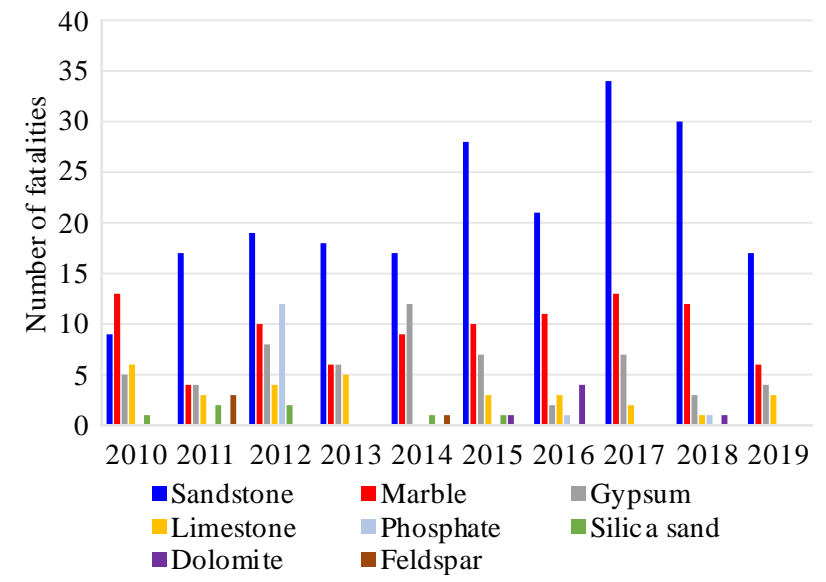

Figure 1. Comparison of fatalities in various surface mines of Pakistan during 2010-2019

In developing countries the work related fatalities are more than the developed countries due to unsafe working conditions [13]. The fatality rate in the surface mines of Pakistan is much higher as shown in Figure 2 by comparing it with fatality rate of the surface mines of USA [14].

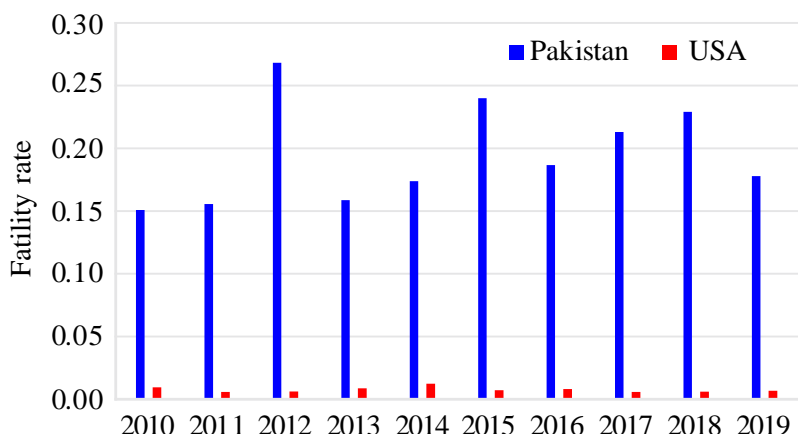

Figure 2. Comparison of fatality rate in surface mines of Pakistan with USA

Figures 1 and 2 show that the working environment in surface mines of Pakistan is worse as such no consistent decrease in fatalities is observed in the last ten years. The fatality rate is of high concern and needed to be addressed. Therefore, this study was undertaken to investigate and analyze the main causes of accidents in the surface mines of Pakistan. For this purpose the accident data reported to Inspectorate of Mines Department and the occupational safety data collected from surface mines were evaluated together to identify the root causes of accidents.

\subsection{Literature survey}

Accident is an unwanted event and occur due to various factors. The risk of accidents occurrence depends on the mine working condition and the safety system followed. Although all the accidents cannot be prevented but the intensity can be minimized up to some extent with strategic safety planning.

Miners are exposed to number of potential health and safety hazards at workplace. Zhang et al, reported that Mine
Safety and Health Administration (MSHA) recorded 137 fatalities related to haul truck in mining operations in United States from 1995 to 2011 [15]. The analysis of the accident data reported to the Inspectorate Division of Mineral of Ghana from 2008 to 2017 shows that $90 \%$ of all fatalities and $85 \%$ of all injuries are due to mining equipment at sites [16]. Kecojevic analyzed the mine accidents data and reported that from 1978 to 1998 in surface mining of US, the two factors fly rock and unsecure blast area account for approximately $68 \%$ of all explosive blasting related injuries [4].

Due to hazardous nature of the surface mines, a suitable safety system is important in order to reduce the number and severity of the accidents. Unsafe conditions, lack of proper inspections, noncompliance of occupational health and safety measures are the common causes of accidents in mines [17]. The human error is the most common factor in the causation of accidents in mining and need to be incorporated on priority basis in safety management [18]. Chen et al. suggested that reforms in the safety laws and strengthening of the local regulation department are important to ensure safety in mining [19].

Furthermore, safety training and technological developmental skills are important for accident prevention and safety management. Management commitment to safety and everyone's responsibility to workplace safety are important tools to enhance accident prevention. Globally, organizations make effort for a zero accident vision with risk management programs.

There are numerous approaches in literature for the identification and management of hazards for mine safety. Various risk assessment techniques were used to find out the basic causes of accidents in mines. Zhang et al used fault tree analysis method to find the root causes of the fatal accidents occurred due to haul trucks in surface mines [15]. National Institute of Occupational Safety and Health (NIOSH) in 2008 used the Major Hazards Risk Assessment (MHRA) method to assess and eliminate the major hazards that causes accidents in the US mineral industry [20]. Recently the Decision Matrix Risk-Assessment (DMRA) procedure was used to identify the hazardous activities, assess the risks and to propose the control measures for better working environment [21].

Khanzode et al. proposed a systematic procedure based on Weibull-distribution and Poisson-distribution models starting from the identification of recurring hazards, then evaluation and periodic monitoring of these hazards of the underground coal mines by using the principles of Control Chart [22]. Sari et al. proposed a risk assessment methodology considering two factors of accidents, level of hazard and probability of its occurrences for underground coal mines [23]. Based on literature study it has been revealed that fault tree analysis (FTA) technique is one of the most versatile technique that give more effective results for risk assessment. Therefore, in this research FTA techniques is applied for risk analysis in surface mines.

\section{Materials and methods}

To achieve the objective of the research, the accidents data from 2010 to 2019 was collected from Inspectorate of Mines Department and also questionnaire survey was conducted in sandstone, marble, gypsum, limestone, phosphate, silica sand, dolomite and feldspar surface mines of Pakistan. In questionnaire survey data regarding various types of hazards present in the surface mines were acquired from mine 
workers and supervisors at the mine sites. The relevant literature is also considered throughout the research carried out. The main task of this study is the identification of the root causes of accidents in surface mines with risk analysis technique.

\subsection{Fault tree analysis}

Fault tree analysis is a logical Top-Bottom technique used for resolving an undesired event into its root causes [24]. In FTA specific logic symbols and specific diagrams are used stepwise logically to show the relationships in events from top to bottom [25]. This analysis is used to identify those root causes that contribute in the causation of undesired Top-Event [26] so that it could be removed to reduce the number of accidents. This technique is used by nuclear industry from years [25] and now it is used by many Industries like transportation [27], aviation, power [28], [29] construction [30], chemical [31] and mining [32]. Some of the symbols used in Fault Tree are given Table 1.

In this study the fault tree is developed to identify the common hazards and associated risks in surface mines which are in the form of human unsafe behaviors, weakness in the safety system, lack of education and lack of rules and regulations. The fault tree is developed on the basis of three groups of elements/factors/causes acquired from the 3 E's Model. The 3 E's model i.e. Engineering, Education and Enforcement was first presented by the National Safety Council United States in 1974 for occupational safety [33]. The elements in the engineering dimension are the safety devices (machines, tools and Personal protective equipment PPE) and environmental factors (dust, noise, temperatures and other workplace hazards), elements in the education category are skills development and safety training related to safety awareness i.e. able to recognize and communicate hazards, and proficiency in work while the elements in enforcement is the preparation and execution of law [34].

Table 1. Symbols of fault tree analysis techniques [25]

\begin{tabular}{l|l}
\hline \multicolumn{1}{c}{ Name } & \multicolumn{1}{c}{ Fymbol } \\
\hline $\begin{array}{l}\text { 1. Top event } \\
\text { 2. Intermediate }\end{array}$ & $\begin{array}{l}\text { 1. Event that is undesirable } \\
\text { 2. Event that need further } \\
\text { analysis }\end{array}$ \\
\hline $\begin{array}{l}\text { And Event or } \\
\text { And Gate }\end{array}$ & $\begin{array}{l}\text { And event is used to indi- } \\
\text { cate that output occur if } \\
\text { both the inputs occur }\end{array}$ \\
\hline OR Event & $\begin{array}{l}\text { OR event is used to indi- } \\
\text { cate that output occur if } \\
\text { any of the inputs occur }\end{array}$ \\
\hline Basic Event & $\begin{array}{l}\text { Main cause of failure/basic } \\
\text { cause/failure event }\end{array}$ \\
\hline Event & $\begin{array}{l}\text { Event in the system/tree } \\
\text { that is not further developed } \\
\text { and is considered as a basic } \\
\text { event. Event in the system } \\
\text { having lack of information }\end{array}$ \\
\hline Transfer Event & $\begin{array}{l}\text { Event in the system/tree } \\
\text { developed in the sub-tree }\end{array}$ \\
\hline
\end{tabular}

\subsubsection{Accidents in surface mines - root causes}

The top event in the fault tree is Accident in Surface Mine as shown below in Figure 3. There are three main branches/parameters of the fault tree obtained from 3 E's Model as discussed earlier in the paper.

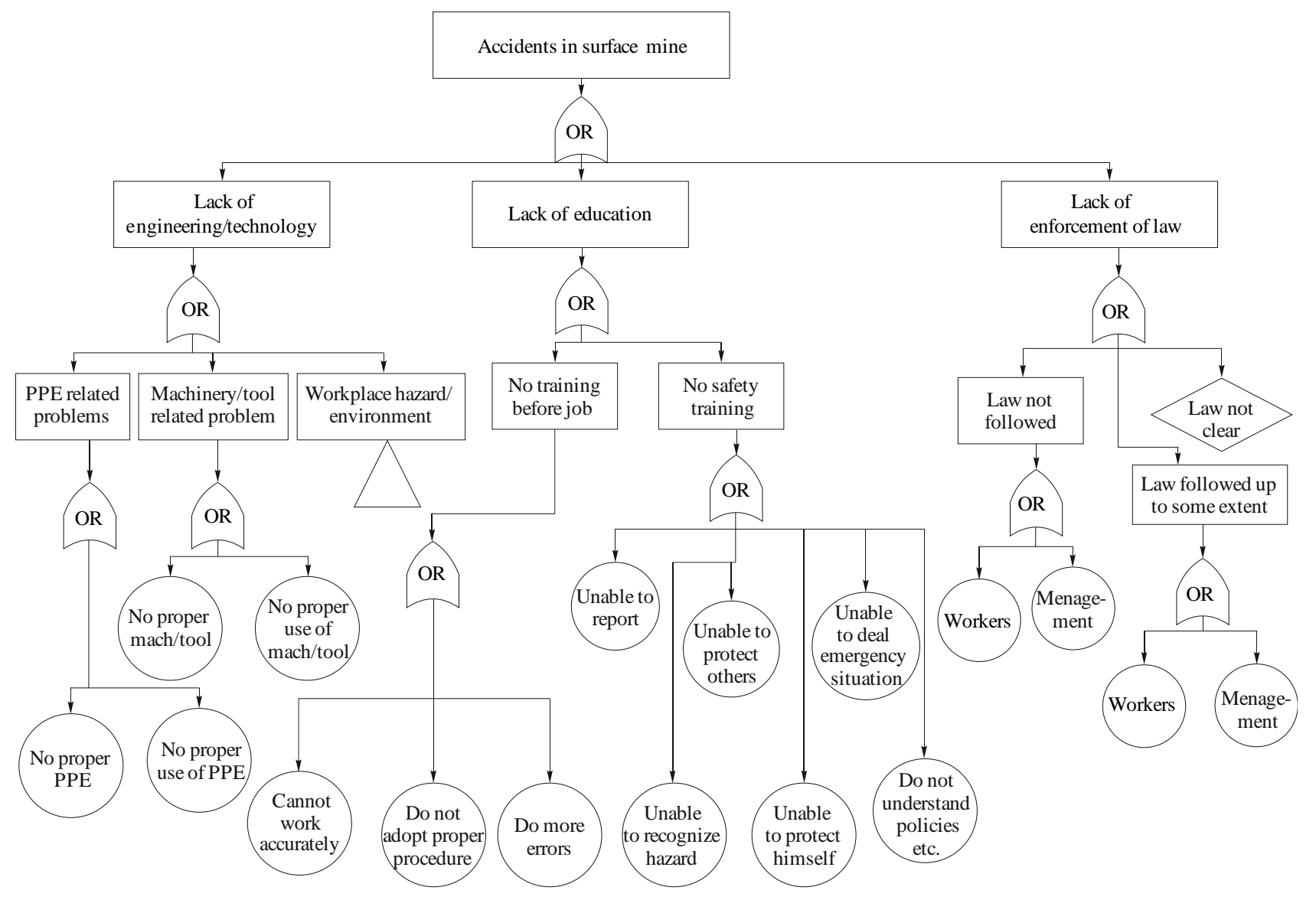

Figure 3. Accidents in surface mines 
The accident can occur due to any one of the three parameters (Lack of engineering/technology, Lack of education and Lack of enforcement of law) which are shown as intermediate events. Further the causes of accidents are displayed as intermediate events and basic events in the fault tree.
The tree also include one transfer symbol pointing to the sub-tree (Fig. 4) and one undeveloped event mean details not available. OR gate is used because accident can occur due to anyone of the cause. The causes are obtained from the accident reports, questionnaire survey and from mine sites.

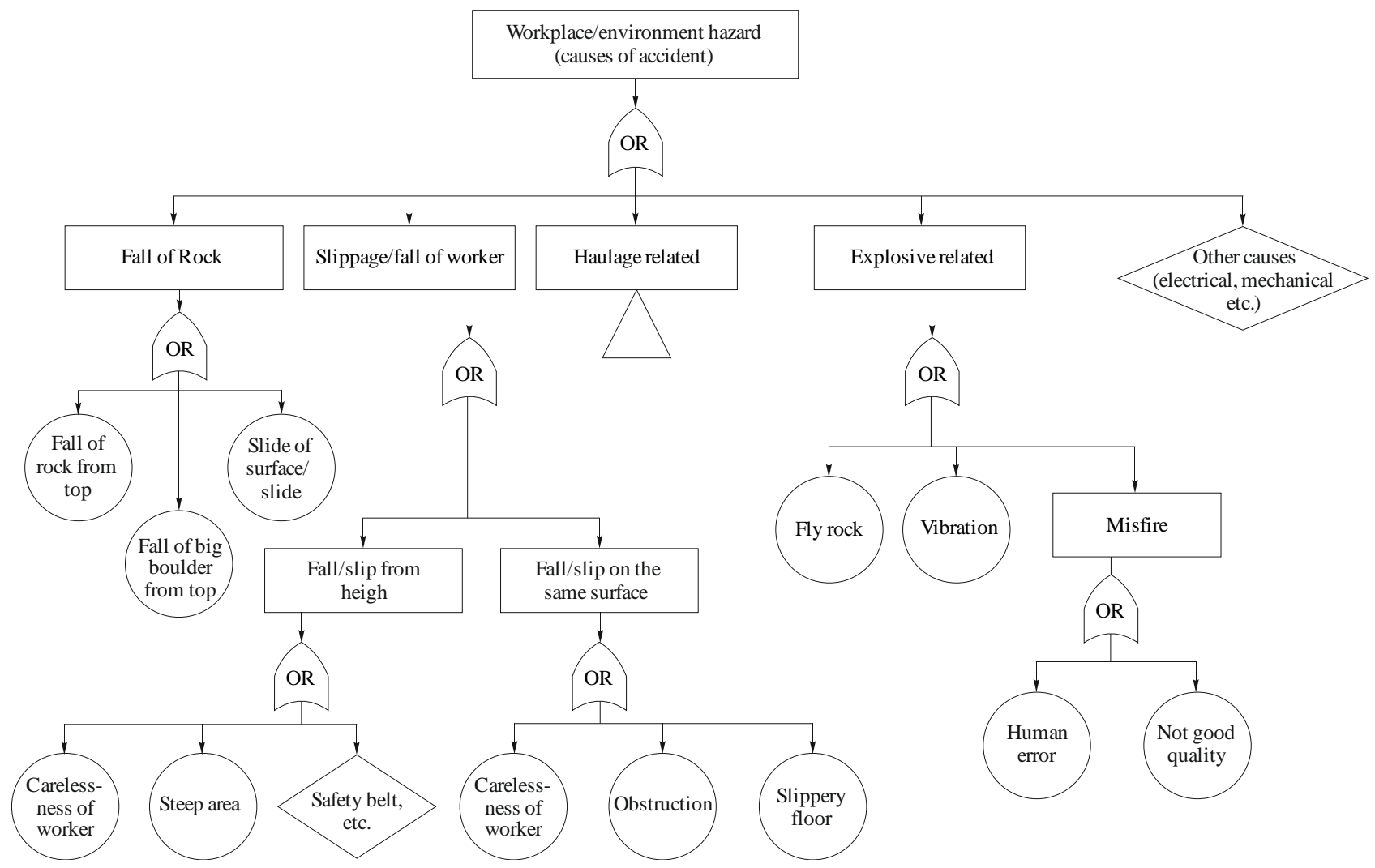

Figure 4. Workplace hazards in surface mines

\subsubsection{Workplace hazards} in surface mines - root causes

Figure 4 illustrate the root causes of accidents related to the mine workplace. The sub-tree shows common physical hazards that contributes in the causation of accidents. This fault tree has one transfer symbol leading to sub-tree (Fig. 5) and two undeveloped events having numerous causes.

\subsubsection{Haulage related hazards - root causes}

Haulage related hazards that cause accidents in surface mines are illustrated in Figure 5 below. The sub-tree provide ten basic events and one undeveloped event as causes of accidents due to haulage.

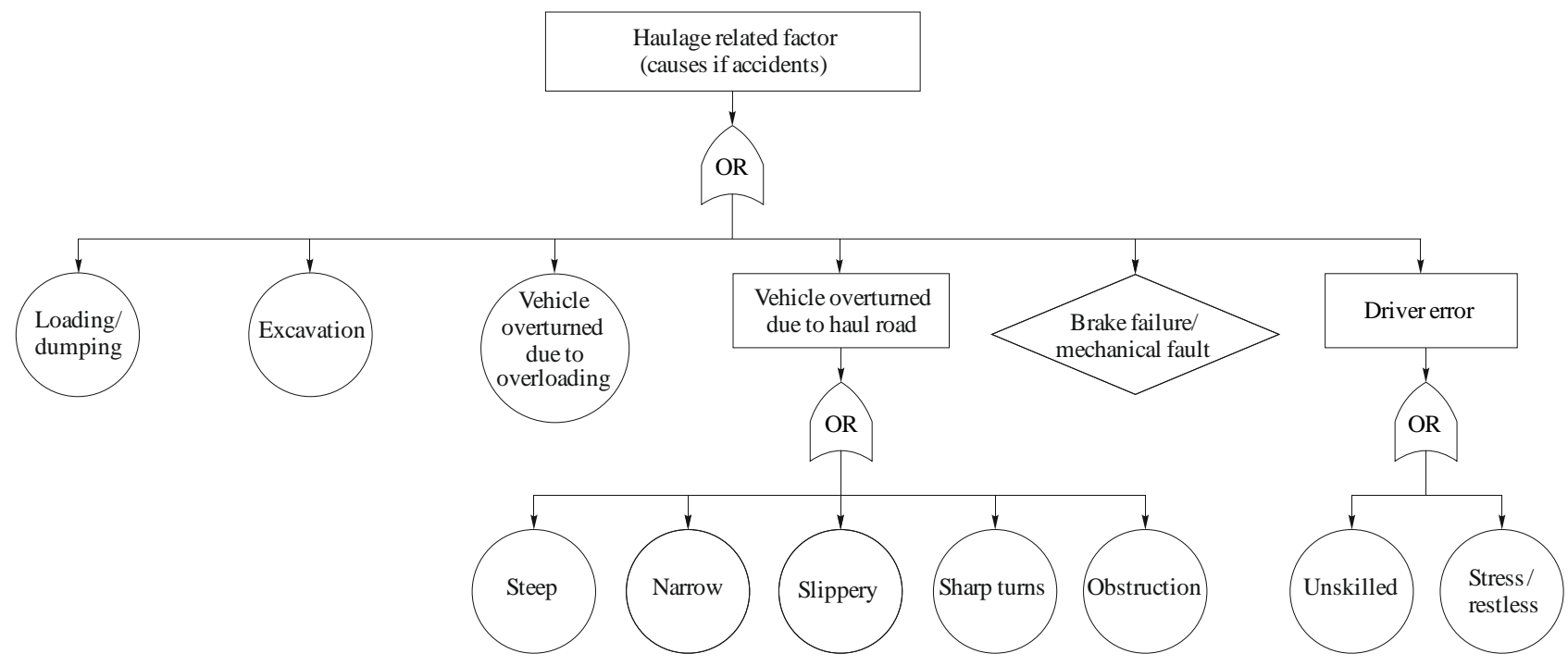

Figure 5. Haulage related hazards in surface mines 


\section{Results and discussion}

There are numerous hazards in surface mines which are the main causes of accidents. Identification of all the hazards present in a mines is difficult. Every mine is unique and has different environment so the hazards are also not all the same. The level of education of workers and management participation is also different in one mine than other mine beside mining method and machinery. But some hazards and their root causes are common in surface mines. The common causes of accident in surface mines are illustrated in the Fault Trees (Figs. 3-5) in the form of intermediate, basic and undeveloped events.

The fault trees present clear picture of the more than forty causes/events due to which accidents occur in mines. The result of the fault trees show that "Lack of engineering/technology" which is concerned with the design, procedure and environment has total of 13 intermediate events with 26 basic events and 3 undeveloped events details including 4 intermediate events with 4 basic events in Figures 3 and 7 intermediate events with 12 basic events and 2 undeveloped events from sub-tree in Figure 4 and 2 intermediate with 10 basic events and 1 undeveloped event from sub-tree in Figure 5.

While "Lack of education" is about lack of basic skills and safety training has 2 intermediate and 9 basic events as illustrated in Figure 4 and "Lack of Enforcement of law" is about the mode of following the rules and regulations in mines which has 2 intermediate, 4 basic and 1 undeveloped event as described in Figure 5. The hazards in surface mines along with the root causes and risk associated and preventive measures are thoroughly discussed below in Tables 2-4.

Table 2 demonstrates the details of the risk analysis for the event "Lack of Engineering/Technology" with common risk associated and preventive measures. By adopting the proper precautionary measure in workplace accident can be controlled in number and severity.

Table 3 shows the details of the risk analysis for the event "Lack of Education". Lack of technical training and lack of safety training are the common problems in most of mines. With proper education and training hazards can be reported/eliminated on time and safety can be enhanced.

Table 4 explains the details of the risk analysis for the event "Lack of Enforcement of Law". In mostly mines law is not properly followed. Law should be enforced in every mines to reduce accidents and improve safety.

The preventive measures are adapted from various well known organization MSHA [35], [36], Occupational Safety and Health Administration (OSHA) [37], National Institute for Occupational Safety and Health and Occupational Safety and Health and Occupational Safety and Health Administration (NIOSH) [20], [38], safety reports [39]-[42] and research publications [3], [43].

Table 3. Risk analysis for accidents in surface mines based on $2^{\text {nd }}$ cause (lack of education)

\begin{tabular}{|c|c|c|c|}
\hline $\begin{array}{c}\text { Hazard sources } \\
\text { (intermediate } \\
\text { events) }\end{array}$ & $\begin{array}{c}\text { Root causes } \\
\text { (basic events and } \\
\text { undeveloped events) }\end{array}$ & Risk associated & Preventive measures \\
\hline $\begin{array}{l}\text { Lack } \\
\text { of technical } \\
\text { training }\end{array}$ & $\begin{array}{l}\text { - cannot work accurately; } \\
\text { - don't adopt proper } \\
\text { procedure; } \\
\text { - do more mistakes. }\end{array}$ & $\begin{array}{l}\text { - more chances of fatal accidents; } \\
\text { - chances of serious and minor - } \\
\text { injuries are also high; } \\
\text { - damage to mine and concerned } \\
\text { machinery and vehicle etc. }\end{array}$ & $\begin{array}{l}\text { - only skilled person should be allowed for work; } \\
\text { - if not properly trained appoint as a trainee; } \\
\text { - technical training should be arranged immediately when } \\
\text { new equipment is installed or new procedure is adopted. }\end{array}$ \\
\hline $\begin{array}{l}\text { Lack } \\
\text { of safety } \\
\text { training }\end{array}$ & $\begin{array}{l}\text { - unable to recognize } \\
\text { hazards; } \\
\text { - unable report hazard; } \\
\text { - unable to protect him- } \\
\text { self from hazards; } \\
\text { - unable to protect others } \\
\text { from hazards; } \\
\text { - don't understand } \\
\text { policies etc.; } \\
\text { - unable to deal } \\
\text { emergency situation. }\end{array}$ & $\begin{array}{l}\text { - more chances of fatal accidents; } \\
\text { - chances of serious and minor - } \\
\text { injuries are also high; } \\
\text { - damage to mine and concerned } \\
\text { machinery and vehicle etc. }\end{array}$ & $\begin{array}{l}\text { - safety training should be compulsory for everyone in the } \\
\text { workplace; } \\
\text { - time to time refresher safety training must be arranged for } \\
\text { the worker; } \\
\text { - training should be arranged to create awareness regarding } \\
\text { hazards identification and safety system followed; } \\
\text { - trainings on policies, safe work procedure should be } \\
\text { arranged on regular basis. }\end{array}$ \\
\hline
\end{tabular}

Table 4. Risk analysis for accidents in surface mines based on $3^{\text {rd }}$ cause (lack of enforcement of law)

\begin{tabular}{|c|c|c|c|}
\hline $\begin{array}{c}\text { Hazard sources } \\
\text { (intermediate } \\
\text { events) }\end{array}$ & $\begin{array}{c}\text { Root causes } \\
\text { (basic events and } \\
\text { undeveloped events) }\end{array}$ & Risk associated & Preventive measures \\
\hline $\begin{array}{l}\text { Law not } \\
\text { followed }\end{array}$ & $\begin{array}{l}\text { - not followed by wor- } \\
\text { kers; } \\
\text { - not followed by } \\
\text { management. }\end{array}$ & $\begin{array}{l}\text { - more chances of fatal accidents; } \\
\text { - chances of serious and minor - } \\
\text { injuries are also high; } \\
\text { - damage to mine and concerned } \\
\text { machinery and vehicle etc. }\end{array}$ & $\begin{array}{l}\text { - proper law should be implemented to avoid any mishap; } \\
\text { - safety training must be arranged on regular basis to create } \\
\text { awareness regarding importance of law; } \\
\text { - penalty must be introduce if law in not followed. }\end{array}$ \\
\hline \multirow[t]{2}{*}{$\begin{array}{l}\text { Law followed } \\
\text { up to some } \\
\text { extent }\end{array}$} & $\begin{array}{l}\text { - followed up to some } \\
\text { extent by workers; } \\
\text { - followed up to some } \\
\text { extent by management. }\end{array}$ & $\begin{array}{l}\text { - chances of minor injuries, } \\
\text { serious injuries and fatality; } \\
\text { - damage to mine and concerned } \\
\text { machinery and vehicle etc. }\end{array}$ & $\begin{array}{l}\text { - proper law should be implemented to avoid any mishap; } \\
\text { - safety training must be arranged on regular basis to create } \\
\text { awareness regarding importance of law; } \\
\text { - penalty must be introduce if law in not followed. }\end{array}$ \\
\hline & $\begin{array}{l}\text { - law not clear } \\
\text { (several causes) }\end{array}$ & - fatal results & $\begin{array}{l}\text { - inspectorate of mines should ensure the law in mines } \\
\text { and remove ambiguity if there. }\end{array}$ \\
\hline
\end{tabular}


Table 2. Risk analysis for accidents in surface mines based on $1^{\text {st }}$ cause (lack of engineering/technology)

\begin{tabular}{lll}
\hline $\begin{array}{c}\text { Hazard sources } \\
\text { (intermediate } \\
\text { events) }\end{array}$ & \multicolumn{1}{c}{$\begin{array}{c}\text { Root causes } \\
\text { (basic events and } \\
\text { undeveloped events) }\end{array}$} & \multicolumn{1}{c}{ Risk associated } \\
\hline $\begin{array}{l}\text { Personal } \\
\text { protective }\end{array}$ & - no proper PPE; & $\begin{array}{l}\text { - injury to head and other body } \\
\text { equipment (PPE) }\end{array}$ \\
$\begin{array}{l}\text { related root } \\
\text { causes }\end{array}$ & $\begin{array}{l}\text { parts etc.; } \\
\text { - respiratory, hearing and skin } \\
\text { problems. }\end{array}$ \\
\end{tabular}

\begin{tabular}{ll}
\hline $\begin{array}{l}\text { Machinery/tool } \\
\text { related }\end{array}$ & no proper \\
problems & machinery/tool.
\end{tabular}
- health effects related to dust, noise and vibration;
- chance of entrapment by machinery; - chance of minor cut due to sharp edges or serious injury; - chance of fire and related damages.

Preventive measures - helmet should be used to avoid hitting by hard things/rock etc.; - proper gloves should be used for hand work;
- mask should be used to reduce inhalation of dust etc.;
- proper clothing to avoid any skin contact with hazardous substances;
- proper clothing to avoid entrapment in machinery.
- use of proper machinery, tools etc.;
- skills to develop to properly use the machinery;
- sharp edges should be deal with care;
- remove defects from machinery on time;
- use of PPE related to machinery;
- if caught fire, proper firefighting equipment
should be available to control on time.

\begin{tabular}{|c|c|c|c|}
\hline \multicolumn{4}{|c|}{ Workplace Hazards/Environment } \\
\hline $\begin{array}{l}\text { Fall of rock/ } \\
\text { Sliding of rock }\end{array}$ & $\begin{array}{l}\text { - fall of small loose } \\
\text { rock/rocks; } \\
\text { - fall of boulder/ } \\
\text { boulders; } \\
\text { - sliding of surface. }\end{array}$ & $\begin{array}{l}\text { - minor injury, serious injury } \\
\text { or fatality to the workers; } \\
\text { - damage to the machinery, } \\
\text { vehicle, mine/property. }\end{array}$ & $\begin{array}{l}\text { - practice mechanized mining instead of conventional mining } \\
\text { method; } \\
\text { - examination before shift start; } \\
\text { - examination after drilling and blasting; } \\
\text { - use of related PPE for protection; } \\
\text { - safety training to recognize and protect himself from hazard. }\end{array}$ \\
\hline \multicolumn{4}{|c|}{ Fall/Slippage of Worker } \\
\hline $\begin{array}{l}\text { Fall/Slip } \\
\text { on the same } \\
\text { surface }\end{array}$ & $\begin{array}{l}\text { - carelessness of worker; } \\
\text { - obstruction on surface; } \\
\text { - slippery floor. }\end{array}$ & $\begin{array}{l}\text { - minor injury; } \\
\text { - serious injury; } \\
\text { - fatality to the workers. }\end{array}$ & $\begin{array}{l}\text { - take care on slippery or wet ground; } \\
\text { - remove obstruction from floor; } \\
\text { - use of related PPE for protection; } \\
\text { - safety training to recognize and protect himself from hazard. }\end{array}$ \\
\hline & $\begin{array}{l}\text { - improper way of } \\
\text { loading/ dumping; } \\
\text { - inappropriate way } \\
\text { of excavation. } \\
\text { - vehicle overturned due } \\
\text { to overloading; }\end{array}$ & \multirow[t]{4}{*}{$\begin{array}{l}\text { - minor injury of worker; } \\
\text { - serious injury; } \\
\text { - fatality; } \\
\text { - damage to vehicle. }\end{array}$} & \multirow{4}{*}{$\begin{array}{l}\text { - only skilled driver should drive; } \\
\text { - vehicle should be checked properly before starting; } \\
\text { - care should be taken if haul roads are narrow, steep or slippery; } \\
\text { - care must be taken if there are sharp turns or frequent turns; } \\
\text { - avoid short cuts. } \\
\text { - don't overload the trucks. } \\
\text { - the loaded truck must drive slowly to avoid any overturned; } \\
\text { - the haul road should of proper slope and width, not slippery } \\
\text { and obstruction free; } \\
\text { - the turns must also be smooth to avoid inconvenience; } \\
\text { - to avoid any type of brake failure or mechanical fault, vehicle } \\
\text { must be checked regularly; } \\
\text { - driver must be properly trained; } \\
\text { - driver must know about the site problems. }\end{array}$} \\
\hline Haul road & $\begin{array}{l}\text { - steep; } \\
\text { - narrow; } \\
\text { - slippery; } \\
\text { - sharp turns; } \\
\text { - obstructions. }\end{array}$ & & \\
\hline & $\begin{array}{l}\text { - brake failure/mechani- } \\
\text { cal fault (several causes) }\end{array}$ & & \\
\hline Driver Error & $\begin{array}{l}\text { - unskilled; } \\
\text { - stress/restless. }\end{array}$ & & \\
\hline \multicolumn{4}{|c|}{ Explosive related Hazards } \\
\hline & $\begin{array}{l}\text { - fly rocks; } \\
\text { - vibration; } \\
\text { - premature blast; } \\
\text { - human error; } \\
\text { - not good quality } \\
\text { explosive; } \\
\text { - lack of security in } \\
\text { blast area. }\end{array}$ & $\begin{array}{l}\text { - minor injury of worker; } \\
\text { - serious injury; } \\
\text { - fatality; } \\
\text { - damage to property. }\end{array}$ & $\begin{array}{l}\text { - avoid unnecessary blasting; } \\
\text { - before blasting it must be ensured that everyone is in safe } \\
\text { place; } \\
\text { - only skilled short firer should be appointed for blasting; } \\
\text { - good quality of explosives, safety fuse etc. should be used; } \\
\text { - required quantity of explosive should be used to avoid fly } \\
\text { rocks and vibration; } \\
\text { - misfire should be handled properly safety training is } \\
\text { important to ensure safety. }\end{array}$ \\
\hline & $\begin{array}{l}\text { Others causes (electric } \\
\text { shock, mechanical, heat } \\
\text { stroke etc.) (several } \\
\text { causes }\end{array}$ & - mostly fatality & $\begin{array}{l}\text { - use good quality of electric appliances and cables; } \\
\text { - if damaged should be repaired on time; } \\
\text { - use PPE to be safe from electric shocks; } \\
\text { - consider the intensity of temperature on site, avoid working } \\
\text { in too hot temperature; } \\
\text { - take proper rest and food to avoid any health problem. }\end{array}$ \\
\hline
\end{tabular}




\section{Conclusions}

In mining industry, safety risk identification and management is an effective step for reducing accidents. Safety status of workplaces can be improved by proper implementation of safety management policies. In this research work, risk analysis for the surface mines accidents is carried out thoroughly. Fault tree analysis method was applied to provide a visual representation of the root causes of surface mine accidents. More than forty root causes of accidents are identified through fault tree techniques. The main causes of accidents identified are human errors, lack of proper machinery and personal protective equipment, environmental hazards, absence of safety training and violation of rules and regulations. Other causes include fall/slide of rock, fall/slippage of workers, haulage and explosive related hazards. The root causes with associated risks are presented and their preventive measures are suggested for enhancing safety in mines. This risk management based approach is helpful in the reduction of mine accidents and improvement of health and safety of workers. It is recommended that effective risk assessment system should be implemented in every mine to identify the hazard on time for safe practices and safe environment.

\section{Acknowledgements}

The authors gratefully acknowledge the time and relevant information provided by the Inspectorate Departments of Pakistan and the supervisors and workers at the mine sites during data collection.

\section{References}

[1] Christidis, G.E. (2011). Industrial minerals: significance and important characteristics. Advances in the Characterization of Industrial Minerals, 9(1) 1-11. https://doi.org/10.1180/emu-notes.2010.emu9-1

[2] Famewo, E.B., Clarke, A.M., \& Afolayan, A.J. (2018). Evaluation of important mineral nutrients and vitamins in polyherbal medicines used for the treatment of tuberculosis in the Eastern Cape Province, South Africa. International Journal of Phytomedicine, 10(1), 16. https://doi.org/10.5138/09750185.2139

[3] Abbasi, S. (2018). Defining safety hazards \&amp; risks in mining industry: A case-study in United States. Asian Journal of Applied Science and Technology, 2(2), 1071-1078.

[4] Kecojevic, V., \& Radomsky, M. (2005). Flyrock phenomena and area security in blasting-related accidents. Safety Science, 43(9), 739-750. https://doi.org/10.1016/j.ssci.2005.07.006

[5] Patterson, J., \& Shappell, S. (2008). Analysis of mining incidents and accidents in Queensland, Australia - from 2004-2008 using the HFACS-MI framework, $37 \mathrm{p}$.

[6] Santos, B.R., Porter, W.L., \& Mayton, A.G. (2010). An analysis of injuries to haul truck operators in the U.S. mining industry. Proceedings of the Human Factors and Ergonomics Society Annual Meeting, 54(21), 1870-1874. https://doi.org/10.1177/154193121005402109

[7] Pera, L.S., Vintró, C., \& Freijo, M. (2012). Characteristics of the 3 most common types of occupational accident in Spanish sub-surface and surface mining, from 2003-2008. DYNA (Colombia), 79(172), 118-125.

[8] Elenge, M., Leveque, A., \& De Brouwer, C. (2013). Occupational accidents in artisanal mining in Katanga, D.R.C. International Journal of Occupational Medicine and Environmental Health, 26(2), 265-274. https://doi.org/10.2478/s13382-013-0096-0

[9] Strzalkowski, P. (2019). Statistical analysis of workplace accidents in Polish mining industry. IOP Conference Series: Earth and Environmental Science, 362(1). https://doi.org/10.1088/1755-1315/362/1/012033

[10] BS ISO 31000. (2018). Risk management - Guidelines. Geneva, Switzerland: BSI Standards Publication, $26 \mathrm{p}$.

[11] ISO 8894-2. (2001). International standard 61010-1. Geneva, Switzerland: International Electrotechnical Commission, 13 p.

[12] Luko, S.N. (2013). Risk management principles and guidelines. Quality Engineering, 25(4), 451-454. https://doi.org/10.1080/08982112.2013.814508

[13] Khan, M.I. (2013). Developing a safety culture in developing countries. Proceedings of the International Conference on Safety, Construc- tion Engineering, and Project Management Issues, Challenges and Opportunities in Developing Countries.

[14] MSHA. (2019). Metal/nonmetal fatalities for 1900 through 2020 United States Department of Labour. Retrieved from: https://arlweb.msha.gov/stats/centurystats/mnmstats.asp

[15] Zhang, M., Kecojevic, V., \& Komljenovic, D. (2014). Investigation of haul truck-related fatal accidents in surface mining using fault tree analysis. Safety Science, 65(7), 106-117. https://doi.org/10.1016/j.ssci.2014.01.005

[16] Stemn, E. (2019). Analysis of injuries in the ghanaian mining industry and priority areas for research. Safety and Health at Work, 10(2), 151165. https://doi.org/10.1016/j.shaw.2018.09.001

[17] Küçük, F.C.U., \& Ilgaz, A. (2015). Causes of coal mine accidents in the world and Turkey. Turk Toraks Dergisi, 16(1), 9-14. https://doi.org/10.5152/ttd.2015.003

[18] Kumar, P., Gupta, S., Agarwal, M., \& Singh, U. (2016). Categorization and standardization of accidental risk-criticality levels of human error to develop risk and safety management policy. Safety Science, (85), 88-98. https://doi.org/10.1016/j.ssci.2016.01.007

[19] Chen, S. Sen, Xu, J.H., \& Fan, Y. (2015). Evaluating the effect of coal mine safety supervision system policy in China's coal mining industry: A two-phase analysis. Resources Policy, 46(P2), 12-21. https://doi.org/10.1016/j.resourpol.2015.07.004

[20] Iannacchione, A., Varley, F., \& Brady, T. (2008). The application of major hazard risk assessment (MHRA) to eliminate multiple fatality occurrences in the minerals industry. Spokane, United States: DHHS (NIOSH) Publication, $142 \mathrm{p}$.

[21] Rivera, C., Villanueva, I., María, P., \& Peña, P. (2019). Analysis and evaluation of risks in underground mining using the decision matrix riskassessment (DMRA) technique, in Guanajuato, Mexico. Journal of Sustainable Mining, 18(1), 52-59. https://doi.org/10.1016/j.jsm.2019.01.001

[22] Khanzode, V.V., Maiti, J., \& Ray, P.K. (2011). A methodology for evaluation and monitoring of recurring hazards in underground coal mining. Safety Science, 49(8-9), 1172-1179. https://doi.org/10.1016/j.ssci.2011.03.009

[23] Sari, M., Selcuk, A.S., Karpuz, C., \& Duzgun, H.S.B. (2009). Stochastic modeling of accident risks associated with an underground coal mine in Turkey. Safety Science, 47(1), 78-87. https://doi.org/10.1016/j.ssci.2007.12.004

[24] DeLong, T.W. (1970). A fault tree manual. Master's Thesis. College Station, United States: Texas A\&M University, $60 \mathrm{p}$.

[25] Aeronautics, N. (1971). Reliability computation using fault tree analysis. Retrieved from https://ntrs.nasa.gov/citations/19720005773

[26] Nebosh. (2016). Fault tree analysis (FTA) and event tree analysis (ETA). NEBOSH National Diploma - Unit A, 1-9.

[27] Derse, O., \& Göçmen, E. (2019). Transportation mode choice using fault tree analysis and mathematical modeling approach. Journal of Transportation Safety and Security, O(0), 1-19. https://doi.org/10.1080/19439962.2019.1665600

[28] Volkanovski, A., Čepin, M., \& Mavko, B. (2009). Application of the fault tree analysis for assessment of power system reliability. Reliability Engineering and System Safety, 94(6), 1116-1127. https://doi.org/10.1016/j.ress.2009.01.004

[29] Fu, D., Gao, S., Yan, Z., Wu, H., Xu, X., \& Xu, K. (2019). Fault tree analysis of large-scale blackout accidents. E3S Web of Conferences, (118), 1-5. https://doi.org/10.1051/e3sconf/201911801049

[30] Science, E. (2015). Analysis of risk management in construction sector using fault tree analysis Nd their solutions. 2(02), 19-27.

[31] Ariavie, G.O., \& Sadjere, G.E. (2012). Development of fault tree diagram for the production line of a soft drink bottling company in Benin city, Nigeria. Lecture Notes in Engineering and Computer Science, (3), 1498-1505.

[32] Giraud, L., \& Galy, B. (2018). Fault tree analysis and risk mitigation strategies for mine hoists. Safety Science, 110(August), 222-234. https://doi.org/10.1016/i.ssci.2018.08.010

[33] Swuste, P., Gulijk, C. van, \& Zwaard, W. (2010). Safety metaphors and theories, a review of the occupational safety literature of the US, UK and The Netherlands, till the first part of the 20th century. Safety Science, 48(8), 1000-1018. https://doi.org/10.1016/j.ssci.2010.01.020

[34] Vierendeels, G., Reniers, G., van Nunen, K., \& Ponnet, K. (2018). An integrative conceptual framework for safety culture: The Egg Aggregated Model (TEAM) of safety culture. Safety Science, 103(December), 323-339. https://doi.org/10.1016/j.ssci.2017.12.021

[35] Safety, M. (2000). MSHA handbook series accident. Illness Investigations Procedures. Safety and Health (November).

[36] Carlson, D., \& Eggerding, P. (2010). Surface mine supervisor MSHA compliance manual. Houghton, United States: Michigan Technological University.

[37] Michaels, D. (2011). OSHA field safety and health manual. National Journal of Community Medicine, 117-120. 
[38] Peters, L., De Smedt, B., Kumar, N., Kumar, J., Castro-alonso, J.C., Paas, F., \& van Merriënboer, J.J.G. (2017). Advances in human factors in simulation and modeling. Developmental Cognitive Neuroscience, 591(July), 1-9. https://doi.org/10.1007/978-3-319-60591-3

[39] Harms-Ringdahl, L. (2013). Guide to safety analysis for accident prevention. In IRS Riskhantering AB. Retrieved from http://www.irisk.se

[40] Ministry of Labour. (2014). Mining health, safety and prevention review. Final report. Toronto, Canada: Office of the Chief Prevention Officer.
[41] Serowe, J. (2016). Safety in surface mining. Technical Report. Johannesburg, South Africa, University of Johannesburg. https://doi.org/10.13140/RG.2.2.10165.06881

[42] International Labour Office. (2018). Safety and health in opencast mines. Retrieved from https://www.ilo.org/sector/Resources/ publications/WCMS_617123/lang--en/index.htm

[43] Sammarco, J.J., Fisher, T.J., Welsh, J.H., \& Pazuchanics, M.J. (2000). Programmable electronic mining systems: Best practice recommendations (In nine parts). Part 1, 1-10.

\section{Визначення збитків та аналіз ризиків при відкритій розробці корисних копалин на кар'єрах Пакистану із використанням методу аналізу дерева відмов}

\section{С. Шерін, 3.-ур-Рехман, С. Хуссейн, Н. Мохаммад, С. Раза}

Мета. Визначення загального збитку й пов’язаних з ним ризиків, які $є$ першопричинами аварій на кар'єрах Пакистану на основі застосування методу аналізу дерева відмов і розробка способів запобігання аварійним ситуаціям, а також підвищення виробничої безпеки у гірничодобувній промисловості.

Методика. Використано комплексний метод дослідження, який включає збір даних про аварії на кар'єрах 3 відповідних офіційних джерел, збір даних щодо безпеки праці шляхом опитування працівників кар'єрів, метод аналізу дерева відмов на основі трьох груп факторів/причин, пов'язаних з аваріями в кар'єрах - інжиніринг, освіта та виробнича дисципліна - отриманих за допомогою $3 \mathrm{E}$ моделі, а також методи оцінки ризиків і розробка заходів із запобігання аваріям.

Результати. В даному дослідженні ідентифіковані 43 основні причини аварій на кар'єрах, які представлені як основні події та нерозвинені події у деревах відмов. Розкривається стисла картина першопричин аварій на кар'єрі. Основними виявленими причинами є людські помилки, небезпечні робочі процедури, відсутність обладнання, відсутність засобів індивідуального захисту, небезпеки, пов'язані з навколишнім середовищем і транспортуванням, а також порушення закону. Виявлені другорядні причини, пов'язані 3 падінням і обваленням порід, а також транспортуванням вибухових речовин. Рекомендовано кожному кар'єру впровадити ефективну систему оцінки ризиків для своєчасного виявлення небезпеки для безпечних практик та безпечного навколишнього середовища.

Наукова новизна. Вперше виявлені та побудовані візуальні взаємозв'язки причин аварій у відкритих рудниках Пакистану у вигляді схем за допомогою методу аналізу дерева відмов.

Практична значимість. Ідентифіковані причини аварій та запропоновані заходи їх запобігання можуть бути використані для того, щоб ліквідувати або звести до мінімуму кількість і серйозність аварій у відкритих рудниках, що допоможе врятувати життя гірничих робітників і зміцнити економіку.

Ключові слова: визначення шкоди, відкрита розробка, аварії, метод аналізу дерева відмов, оцінка ризиків, заходи запобігання аварій

\section{Определение ущерба и анализ рисков при открытой разработке полезных ископаемых на карьерах Пакистана с использованием метода анализа дерева отказов}

\section{С. Шерин, 3.-ур-Рехман, С. Хуссейн, Н. Мохаммад, С. Раза}

Цель. Определение общего ущерба и связанного с ним рисков, которые являются первопричинами аварий на карьерах Пакистана на основе применения метода анализа дерева отказов и разработка способов предотвращения аварийных ситуаций, а также повышение производственной безопасности в горнодобывающей промышленности.

Методика. Использован комплексный метод исследования, который включает сбор данных об авариях на карьерах из соответствующих официальных источников, сбор данных относительно безопасности труда путем опроса работников карьеров, метод анализа дерева отказов на основе трех групп факторов/причин, связанных с авариями в карьерах - инжиниринг, образование и производственная дисциплина - полученных при помощи 3Е модели, а также методы оценки рисков и разработка мер по предотвращению аварий.

Результаты. В данном исследовании идентифицированы 43 основные причины аварий на карьерах, которые представлены как основные события и неразвитые события в деревьях отказов. Раскрывается сжатая картина первопричин аварий на карьере. Основными выявленными причинами являются человеческие ошибки, небезопасные рабочие процедуры, отсутствие оборудования, отсутствие средств индивидуальной защиты, опасности, связанные с окружающей средой и транспортировкой, а также нарушение закона. Выявлены второстепенные причины, связанные с падением и обрушением пород, а также транспортировкой взрывчатых веществ. Рекомендовано каждому карьере внедрить эффективную систему оценки рисков для своевременного выявления опасности для безопасных практик и безопасной окружающей среды.

Научная новизна. Впервые выявлены и построены визуальные взаимосвязи причин аварий в открытых рудниках Пакистана в виде схем при помощи метода анализа дерева отказов.

Практическая значимость. Идентифицированные причины аварий и предложенные меры их предотвращения могут быть использованы для того, чтобы ликвидировать или свести к минимуму количество и серьезность аварий в открытых рудниках, что поможет спасти жизни горнорабочих и укрепить экономику.

Ключевые слова: определение вреда, открытая разработка, аварии, метод анализа дерева отказов, оценка рисков, меры предотвращения аварий 